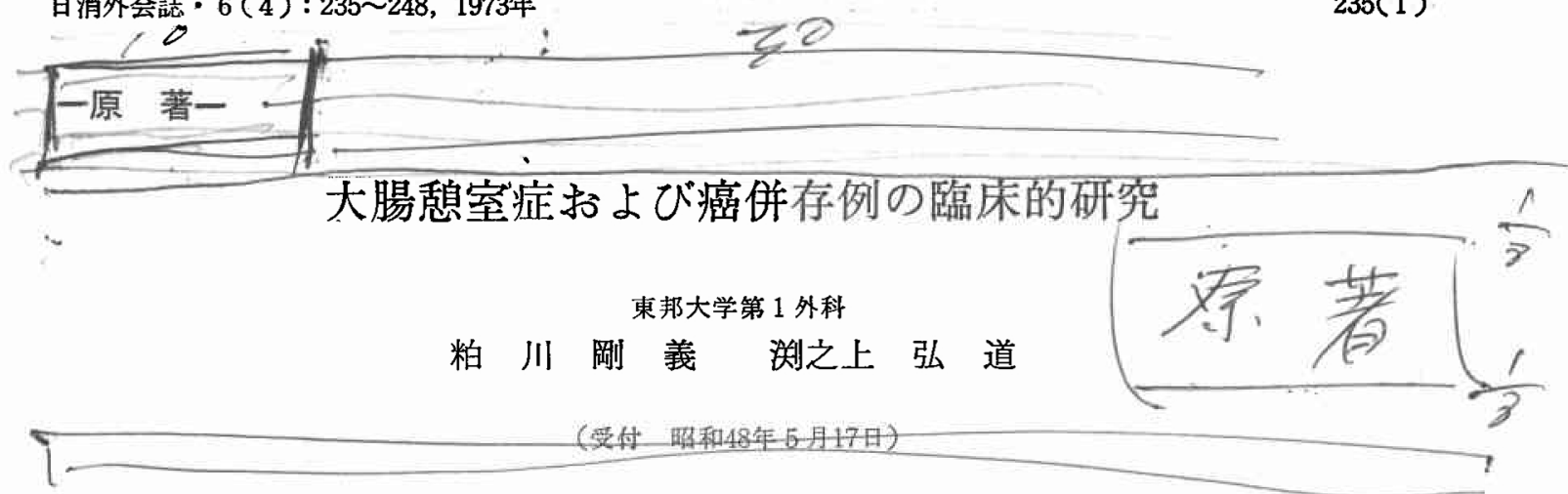

\title{
CLINICAL STUDY ON THE OPERATED COLONIC DIVERTICULAR DISEASE AND CASES OF COEXISTING CARCINOMA
}

\section{Takeyoshi KASUKAWA \\ Hiromichi FUCHINOUE}

1st Department of Surgery, Tohō University School of Medicine

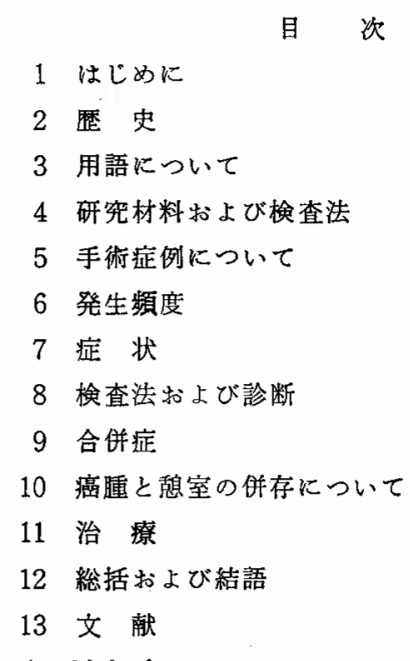

1 はじめに

近年本邦に打いても，大腸䕀室症に対する認識 が高まり，数多くの報告をみるようになつた．本 疾患は欧米に颃いては大腸の一般的な疾患とし て，日常相遇しているといわれている. 本邦でも 最近の報告をみると，その発見率は増加の一途を たどり，決して少ない疾患ではなく，また近い将 来われわれも欧米なみに多くの患者を手近に治療 する機会がくるものと考えられる，大腸喤室症は 生涯無症状で経過するものも多いが，時には種々 の重篤な合併症を惹起し，内科的あるいは外科的 な適切な治療を必要とする，著者はここに手術症 例を中心に大腸蒩室症例括よび癌併存症例を検討 し，併せて若干の 文献考察を行つたので報告す
る.

\section{2 歴史}

大腸憩室症の報告は欧米比いては古く, 1807 年 Somnering ${ }^{12}$ の病理解剖学にみられるといわ れ，1849年 Cruveilhier ${ }^{2)}$ はS 状結腸の嚊室の所見 を記載し，筋層の gap よりの粘膜脱出で，とく に便秘症のある老人にみられると述べている。 1887年 Ball' ${ }^{8)}$ は diverticulitis による colovesical fistula の二症例を示し, 大腸の炎症について病理 解剖学的に検討している. 1899年 Gräser は大腸 想室について, 詳細に記録 $\mathrm{L}$, diverticulitis に癌 が合併するのではないかと指摘した.この報告以 来，多くの人の興味がこの疾患にもたれるように

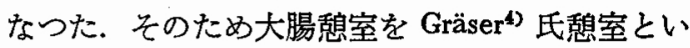
らこともあり，本邦の初期の報告例にもこの言葉 がみられる.1904年 Beer ${ }^{\text {5) }}$ は diverticulitis $の 15$ 症例についての臨床像を報告した．そのなかで彼 はこの疾患は S 状結腸の狭䇤，穿孔による汎発性 腹膜炎，膿瘍形成による限局性腹膜炎， $\mathrm{S}$ 状結腸 膀胖瘦をるたらすと述べている．1907年 $\mathrm{Mayo}^{6}$ は diverticulitis に対して腸切除を行つた症例を 報告し，そのなかで，膿痬や瘦孔が続発する前に 病変部腸管の一次的切除が好ましいと述べて，外 科治療の道を開いた. 以後大腸䅣室症の報告は多 く, 種々の研究がなされるようになつた。しか し, 第二次大戦前までは術後合併症が多く，外科 的治潦の対象になることが少なくもしろ大腸憩室 
症とい兄ば内科的疾患と考学られていた．第二次 大戦後は抗生物質の発展と消毒敊よび医療器具の 進歩とあいまつて, 手術が始めて安全となつた。

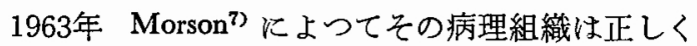
記載され，1969年 Hughes ${ }^{9)}$ は炎症合併が症状を 招くことを臨床, 組織学両面から確認し，1968年 Painter ${ }^{8)}$ は憩室部に圧が高く加わることを報告 した. 最近の報告では病理解剖学的な研究よりも むしろ大腸の内压和よび運動, 腸管支持組織など の関係についての報告が注目されている.

本邦では昭和 9 年（1934年）に園田量 がその第 1 例を報告した.この症例は19歳女性で虫垂炎の 診断のもとに手術を施行したところ，盲腸に炎 症性の単発性毠室をみとめ, 盲腸内埋没法を行 い, 治漓せしめている. 昭和11年(1936年)松尾 ${ }^{10)}$ は憩室性大腸炎の 2 例を報告した。 1 例は横行結 腸に憩室穿孔性膿瘍を認めて䕀室切除術を施行し た. 他例は下行結腸および S 状結腸に喤室穿孔性 膿瘍をみとめ，これを切開排膿したが，後に腸瘦 を形成している．昭和14年（1939年）日下部 ${ }^{12)}$ 横行結腸および $\mathrm{S}$ 状結腸の穿孔性大腸炎の 2 治験 例を報告し，治療は憩室を含めた病変部腸切除を すべきであると主張している．同年武田 ${ }^{133}$ は盲腸 櫋室性大腸炎の 2 症例を発表し，1937年までに世 界で報告された症例は22例に過ぎないと述べて いる．著者の調査によると 22 例以上の報告がみら れる．また蛀炎との鑑別は困難であるが，しか し腸管撮影法ならびに後腹膜撮影法を併用せるレ ントゲン検查を行う時はこれを診断できると述 べている．昭和15年（1940年）橋本 ${ }^{14}$ は虫垂款室 の 2 例を報告し，星野の第 1 例報告についで，第 2 おび第 3 例であると述べている．彼は外科的 に切除した122個の虫垂について組織学的に検査 を行い，2 例を発見している，2 例ともに仮性咊 室で腸間膜附着部に存在していたと報告した. 以

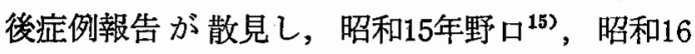
年島田 ${ }^{16)}$ などの腸㦝室（大腸を含む）の総説をみ る. 第二次大戦後は毎年症例報告がみられ，臨床 研究は進み，本邦にお汀る大腸唕室症の実体が明 らかにされてきた.すなわち，その発生頻度は欧 米にくらべ非常に低いこと，したがつて手術症例 も少いこと，癌合併症例はほとんどないこと，熹
室は右側に多く，下行およひ S 状結腸にくる多発 性憩室例が少ないことなどである，わが国では戦 前を大腸憩室症に関する第一期とすると，戦後よ り昭和44〜45年までを第二期とみることができる が，乙かし昭和 $45 〜 46$ 年以後は第三期黄金時代と もいらべき時代で, 従来の発表をはるかに淩駕す る報告が続き，その発生頻度は欧米にほとんど劣 らない湆ど多く，種々の合併症々例拉よび手術症 例が沢山報告されるようになつた。たと竞ば小坂 $5^{17)} 3$ 年 9 力月間に注腸 $\mathrm{X}$ 線検查を1987例飞施 行し，131例の結腸㮩室症を発見したと報告して いる. 吉川ら ${ }^{18)}$ は 1 年 5 力月間に 700 例の検查で 68例を発見し，注腸検查法の改良により発見率を 高めたと報告し, 従来報告が少かつた多発性櫋室 症 (群集性唕室症と発表) を14例 $(20.6 \%)$ 発見 している.これらは大腸櫋室症が日本でも決して 少い疾患ではないことを意味し，今後これらの症 例の研究により, その病因の究明が一刻も早くな されるよう期待し，われわれ臨床家は増加する患 者の適切な治療に，心すべきであると考える．ま た今日のよ5に大腸稳室症の発見率の向上は小出 来ら ${ }^{199}$ の本邦全国集計などによる啓蒙によるとこ ろが大である.

\section{3 用語について}

現在大腸に存在する愳室についての名称は種々 で，その著者により異なる用語と，同一用語でも 意味を異にすることがあり，とくに炎症を伴うも のと伴わないものの用語が判然とせず，混乱を 招いている.たとへば Quervain ${ }^{19)} や$ Case $^{203}$ は diverticulosis という言葉を提唱し，炎症を伴わな いものとしたが, Spriggs \& Marxer ${ }^{22)}$ はこの疾患 の全経過を包含して使用している.すなわち，炎 症を伴うものと伴わないるのが含まれる。これを 日本語では多発性咊室または多発性喤室症とよぶ ことが多く，とくに憩室症には炎症を伴うものに 使用する場合と, 炎症の有無を問わずに広い意味 で使用する場合がある. また数についても，2 以上より 5 〜 ケ前後のものを多発性 (diverticulosis) とよんだり, 散在性 (multiple diverticula) とすることもあり，その意味する内容がかならず しも一致していない. $\mathrm{S}$ 状結腸, $\mathrm{S}$ 状結腸十下行 結腸括よび全結腸に多発する稳室症と単発性また 
は散在性に発生する媳室症とはその病因を異にす ると主張する学者もあり，とくに発生秝室数が 問題となることがあり，その統一が要求されてい る. 炎症を伴らものは通常息室炎 diverticulitis と いら語が使用されているが，稳室周囲炎 peridiverticulitis という言葉もある。両者はたがいに移 行しあうものであり(炎症が)，われわれ臨床家は これをどのように鑑別したらよいのか，治療上の 差異があるのか，また臨床上これを区別する意味 があるのか理解に苦しむ. 確かに病理組織学的に は区別でき，また炎症の発生および波及経過の検 索には重要な言葉であり，病態ではある，著者は 臨床家の立場に立つた用語の統一およびその病態

A 像の統一の必要性を痛感する. 著者は下記のごと く大腸覣室症について規定し，混乱々誤解のない ようにして使用した.

大腸憩室症
Ｉ．大腸憩室：a 単発性
b 散在性
c 多発性

II . 覣室性大腸炎 :

例. a 数室穿孔性汎発性腹膜炎

b 多発性憩室穿孔性 S 状結腸膀胱瘦

c 憩室穿通性子宮 $\mathrm{S}$ 状結腸膿瘍

すなわち，大腸悡室症とはすべての大腸の㮩室 を含み，炎症および合併症の有無を問わない，炎 症和よび合併症を伴わない場合は大腸息室とよ び，これは多くの場合治療の対象にはならず，生 涯無治療に経過する場合が多い，一方炎症扣よび 合㐼症を伴うむのを一括して覟室性大腸炎とい ら、これらはわれわれの治療対象群であり，治療 は内科叔よび外科に及ぶ. 大腸数室とは大腸粘膜 の脱出であり，憩室に炎症があるといらことは脱 出した大腸粘膜またはその周囲組織の炎症で，こ れは限局性にせよ大腸炎にすぎない。この炎症が 種々の病態飞進展すると, 㦝室周囲炎, 膿瘍形 成, 穿通, 穿孔, 出血などを示し, 複雑な臨床像 が形成される.これらはなんらかの治療を必要と するもので，これを一つのグループとしたことは 有意義であると信ずる。 また, colovesical fistula という言葉ではその病因, 病変部は不明確で, た
だちに治療の方針は決定されないのに対して，香 室穿孔性 S 状結腸膀胼瘦といえば, その病因, 病 態扣よび病変部はただちに明瞭であり，その治療 は特のずから決定されるなぞのはつきりした言葉 の規定を行つた.

発生個数を示すには，1 個のものを単発性 と し, spastic colon 様の状態を伴い, 連続性に多数 の咊室が存在するものを多発性とし，これ以外で 賏室が散在するものを散在性とする.ただし今回 注欧米語についての統一は行わない.

\section{4 研究材料および検查法}

昭和 35 年 1 月より昭和 46 年 7 月までに外来拉よ び入院患者で大腸レントゲン透視を行つた者のう ら，全大腸が明瞭に読影できる症例を選んだと ころ, 男子 300 例, 女子 300 例の合計 600 例を兄 た. 1 例毎に敗室の有無を検討したところ，27例 の大腸憩室症々例を見出した。これに昭和 46 年 7 月以後に手術を施行した 5 症例を加兄合計 32 例に ついて検討した.

検查法は腹部単純レントゲン検查, 大腸レント ゲン透視法（その時期により充盈一回法, Fischer 法拈よびその変法, Welin 変法), 直腸鏡検查特よ び大腸フアイバースュープ検査を行い有意義であ つた．診断の項でその方法などを詳述する.

\section{5 手術症例について}

1）柴○伝○令76歳.（癌併存例）（図 1）

第19回日本大腸肛門病学会に教室の杉本が発表 し， $\mathrm{S}$ 状結腸に多発性憩室を認め, 同部にポリポ 一ジスおよび結腸癌が併存していた症例である.

ここで小平教授が追加発言で次のように述べてい る「組織標本でBodenにあまり癌浸潤がなく，潰 瘍面の粘膜および粘膜下層に癌変性がみられた。

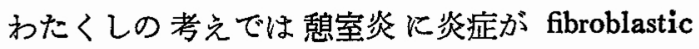
tumor を作り，その粘膜面が癌変性を起したと思 う. この標本をSt. Marks Hospital の Dr. Morson にみてるらつたら，こらいう例はわれわれのとこ ろには沢山めると見せられた。」すなわち，稳室 の炎症部より癌が発生しらることを暗示した症例 である.

2）古○伝○令71歳. (大量出血例) 第21回日本大腸肛門病学会に教室の柏田が発表 した.この症例は腹痛とともに大量の下血を伴 
麦 1 手術症例

\begin{tabular}{|c|c|c|c|c|c|c|c|}
\hline & & 年命 & 性 & $\begin{array}{l}\text { 熄生部位 } \\
\end{array}$ & 性 状 & 合併及び僁存疾患 & 療 \\
\hline *1. 柴O & 伝O & $76 \nsucc$ & $\hat{\delta}$ & $\mathrm{S}$ 状結腊 & 多 発 性 & 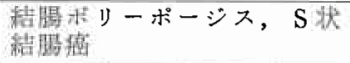 & $\mathrm{S}$ 状結腸切除術 \\
\hline * 2. 古O & 伝O & 717 & $\widehat{\delta}$ & 全 䊅 得 & 多筧性 & 下血 $\rightarrow シ$ 甘 $>ク$ & 左半結腸切除術 \\
\hline 3. 大O & 信○ & $57 \Varangle$ & $\hat{\delta}$ & S 状結腸 & 散 在 性 & 䅣室穿孔性 S 状結腸一膀胱 & $\begin{array}{l}\text { S 状結腸切除術兼瘦孔切除 } \\
\end{array}$ \\
\hline 4. 山○ & 50 & 597 & 우 & $\begin{array}{l}\text { 望腸, 上行 } \\
\text { 横行結腸 }\end{array}$ & 散 在 性 & 敏尿㹺 & 回腸・盲腸切除術 \\
\hline 5. 痛 0 & 国O & $48 \pi$ & 8 & 声腸 & 筆笋性 & & 回腸盲腸切除術 \\
\hline 6. 橋O & 君○ & 247 & 우 & 腸 & 単榮性 & 肺結核 & 秘室切除術 \\
\hline 7. 中○ & 弘 $\mathrm{O}$ & $24 t$ & $\hat{o}$ & $\begin{array}{l}\text { 其腸 } \\
\text { 上行結腸 }\end{array}$ & 散在性 & & 回腸盲腸切除術 \\
\hline 8. 伊O & b० & 487 & q & $\mathrm{S}$ 状䍃且 & 筷発㘹 & & Anterior resection. \\
\hline 9. 松O & 敏 $\mathrm{O}$ & $60 才$ & $\delta$ & $\begin{array}{l}\text { 目腸 } \\
\text { 上行結腸 }\end{array}$ & 多発性 & 非转異性大腸炎，值腸求 》 & 回腸・盲腸切除術 \\
\hline 10. 山○ & 勘○ & 72才 & 8 & 下行結腸 & 多発 性 & イレウス, 下行結腸癌 & 左半結腸切除術 \\
\hline 11. 概 $\bigcirc$ & 貞O & $70 才$ & $\hat{\delta}$ & 全 結 腸 & 多発性 & 直腸癌, 䕀室穿孔性腹膜炎 & ドレナージ, 人工肛門造設術 \\
\hline 12. 大 $\bigcirc$ & 吉○ & $65 \star$ & $\hat{o}$ & $\begin{array}{l}\text { 下㣶 } \\
\mathrm{S} \text { 状結腸 }\end{array}$ & 多発 性 & $\begin{array}{l}\text { ポエッツジャガー症候群, } \\
\text { S 状結腸癌 }\end{array}$ & $\mathrm{S}$ 状結腸切除術 \\
\hline 13. 久○ & 順○ & 517 & q & $\begin{array}{l}\text { 盲腸・上行 } \\
\text { 下行結腸 }\end{array}$ & 多発性 & 上行結腸ポリープ & $\begin{array}{l}\text { 回腸盲腸切除術, 下行結腸 } \\
\text { 部分邪 }\end{array}$ \\
\hline 14. 加 $\bigcirc$ & 高吕 & 577 & 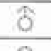 & 粠行䊀腸 & 啭発性 & 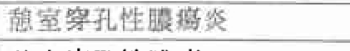 & 1Vレナージ \\
\hline 15. 丸О & 莱全 & & 우 & 䭪 & 単 発 性 & 媳室穿孔性膿瘍 & ドレナーシ \\
\hline 16. 斉○ & 200 & $69 x$ & 9 & S 犾結胆 & 多発 性 & $\mathrm{S}$ 状結腸㾇 & $\mathrm{S}$ 状結腸切除 \\
\hline 17. 佐O & EO & 747 & $\hat{0}$ & S 姑結勝 & 多埕性 & $\mathrm{S}$ 状銡晹㾇 & 人工肛門造設術 \\
\hline
\end{tabular}

図 1 症例 1 癌腫が香室周围に存在（想室一矢印 をまきこんでいる)

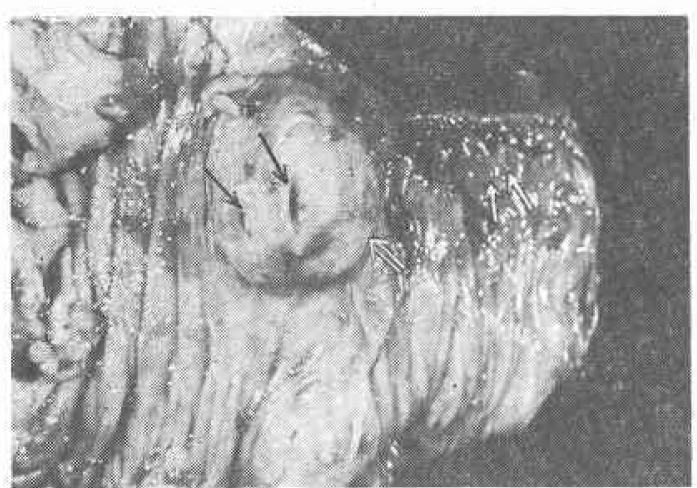

い,一時ショックとなり, 左半結腸切除術にて治 癒した例で，全結腸の多発性颕室であつた。

3）大○信 $\bigcirc$ 今 57 歳.（咊室穿孔性 $\mathrm{S}$ 状結腸膀 胱瘦例).

3 年間におよぶ下腹部痛があり, 治療を続けて いたが，排㽷痛とともに尿中に糞便が混入するよ らになり,当科に転医してきた. 直腸鏡および注腸
透視検査にて，S 状結腸飞憩室と瘦孔を認め, 同 部は反復した炎症のために一塊の腫瘍状となり， あたかも癌と䛊診する汪どであつた. sigmoidectomy と fistulectomy にて治癒した.

4）山○ふ○ 9 59歳.（盲腸悡室性大腸炎例） 下腹部痛，便秘などの症状を示し，腹水怙よび 左下腹部腫瘤を認め, 糖尿病を合併していた。注 腸透視により盲腸，上行結腸および横行結腸に散 在性の唕室を認め, ileocaecotomy を施行して治 癒した.

5）樀○国 $\bigcirc$ 今8歳.（盲腸部㮩室性大腸炎例） 下腹部痛と発熱を認め，排便があると下腹部痛 が軽快し，また便秘に傾くと下腹痛を認める。こ の症状は憩室性大腸炎にかなり特徴的である．注 腸透視により，盲腸部に喤室をみとめ，周囲は大 腸走行異常，変形著明であつた，ileocaecotomy を施行して治瘾した.

6）橋 $\bigcirc$ 君 $\bigcirc$ 9 24墄.（盲腸部秝室性大腸炎例） 白血球増多を伴ら右下腹部痛があり，術前急性 
虫垂炎と診断し，手術したところ，盲腸部腸間膜 附着部に拇指頭大の炎症性嚊室を認めた. diverticulectomy を施行治癒した.

7）中 $\bigcirc$ 弘 $\bigcirc 24$ 歳.（盲腸部憩室性大腸炎例） 右下腹部痛, 便秘㧍よび右下腹部腫瘤触知があ り，注腸透視にて盲腸および上行結腸に炎症性 暿室を認めた. ileocaecotomy を施行して治癒し た。

8）伊○ち○早48歳.（直腸 $\mathrm{S}$ 状結腸部憩室性 大腸炎例)

下血（大量）を主訴として入院し，直腸鏡検查 にて, 肛門縁より $11 \mathrm{~cm}$ 直腸 S 状結腸部に出血性 䄭室を認めた. anterior resectionを施行, 治癒し た. 術後単発性であることを確認した.

9）松○敏○含60歳.（盲腸部憩室性大晹炎例） 下血（多量）和よび下痱を主訴として入院し た. 注腸透視にて盲腸, 上行結腸に多発性䅣室を 確認し, ileocaecotomyを施行し, 治瘾した.

10）山○勘○令72歳.（癌併存例）（図-2, 3)

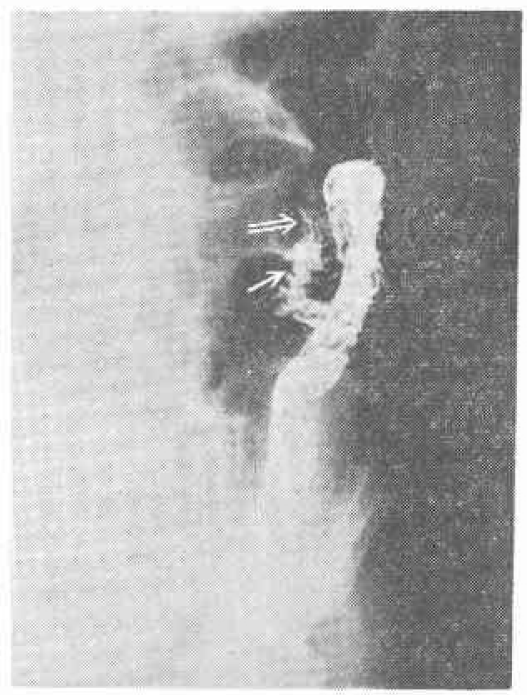

図 2 症例10下行結腸に多数の喤室が認められ, そ の口側に狭窄部一癌腫が存在している。

イレウスにて入院してきた. 腹部単純レントゲ ン写真にて, 拡張した下行結腸を認め, その辺縁 に憩室内のガス像を認めた。注腸透視検査にて下 行結腸に多発性熄室と狭窄部を確認し，さらに大 腸フアイバースコープにて狭窄部に癌腫の存在を

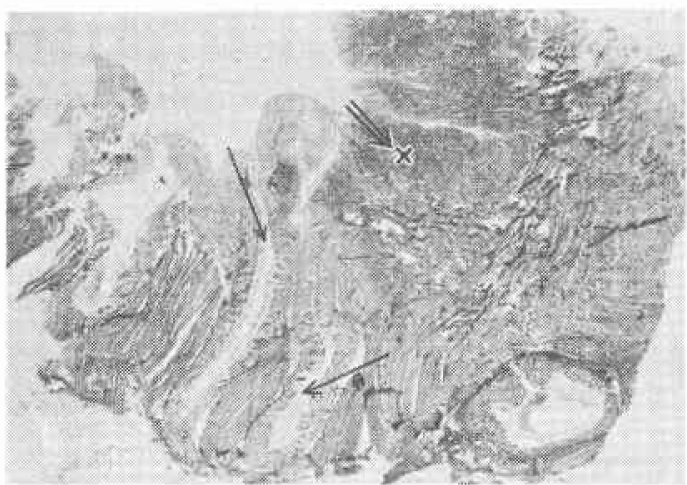

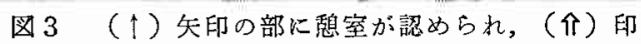
の部に癌瘇が存在, 1 部㮩室壁に浸潤して いる。

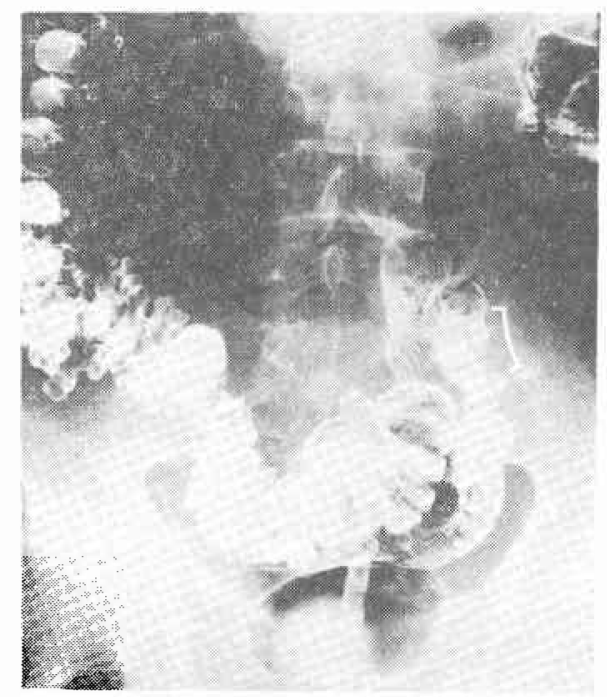

図 4 全結腸に多発性㓤室が存在, $\mathrm{S}$ 状結腸に癌腫 に上る陰影欠損が認められる。

発見した. 左半結腸切除を施行したが，術後不幸 な転帰をとつた。

11）櫛○貞○令 70 歳.（癌併存および憩室穿孔 例) (図-4)

下片と下血（少量）を主訴として入院した．直 腸鏡にて肛門録より $8 \mathrm{~cm}$ 部位に腫湯を認め，試 験切除にて腺癌と診断された. 注腸透視検查を行 ら前処置として，リチネ油 $30 \mathrm{ml}$ を服用させたと ころ 4 時間後に沉発性腹膜炎を併発した. ただら に開腹術を施行したところ，腹腔内には多量の䔬 便性渗出液を認め, 全大腸に多発性憩室が存在 し，S 状結腸穿孔部は款室に接していた，腫瘍は 膀胱拉よび周囲組織に浸潤が著明であり，根治性 
がないものと判断されたので，人工肛門造設術拉 よび drainage を行つた. 不用意なりチネ油投与 が穿孔をきたしたものと反省させられた症例であ る.

12）大○吉○令65歳.（癌括よびPeutz-Jeghers syndrome 併存例) (図-5, 6, 7, 8)

下血（多量）および便秘を主訴として来院し た. 注腸透視検査により, 下行， $\mathrm{S}$ 状結腸に多発 性㮩室を認め, さらにS 状結腸部に陰影欠損部を

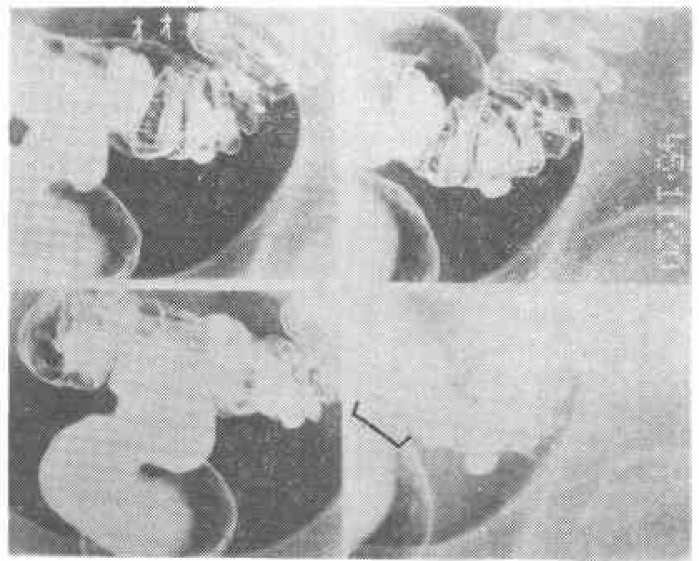

図 5 症例 $12 \mathrm{~S}$ 状結腸（印の部）飞辺縁不整陰影欠 損部を認める。

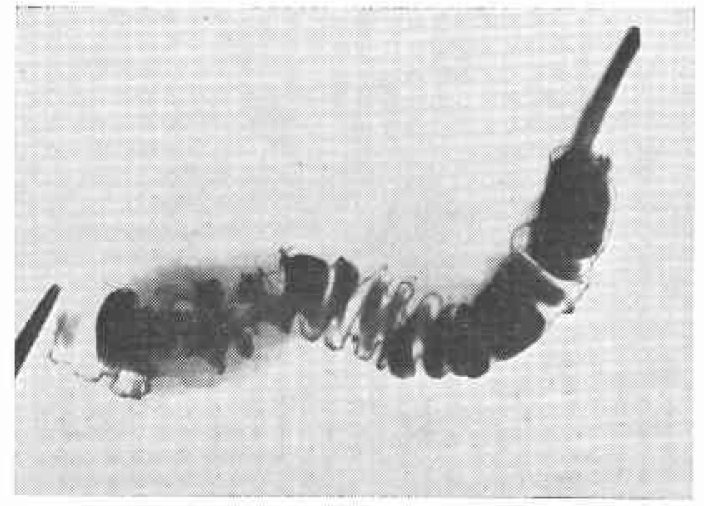

図 6 摘出標本では陰影欠損が明瞭になる。

伴い，癌腫の併存を疑われた，大腸フアイバース コープにて S 状結腸に腫瘍を認め，試験切除にて 腺癌と診断された。 またこの患者は口唇和よび口 腔粘膜に色素斑を認め, Peutz-Jeghers syndrome が疑われた，消化管の精査をしたところ，胃 にポリープを発見できたので亜型 Peutz-Jeghers syndrome と䛦断されためずらしい1例である.

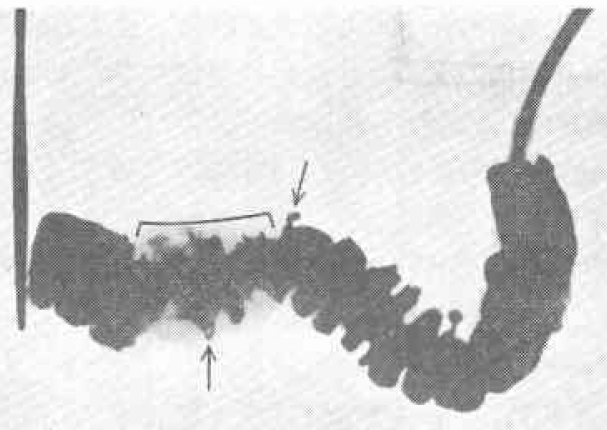

図 7

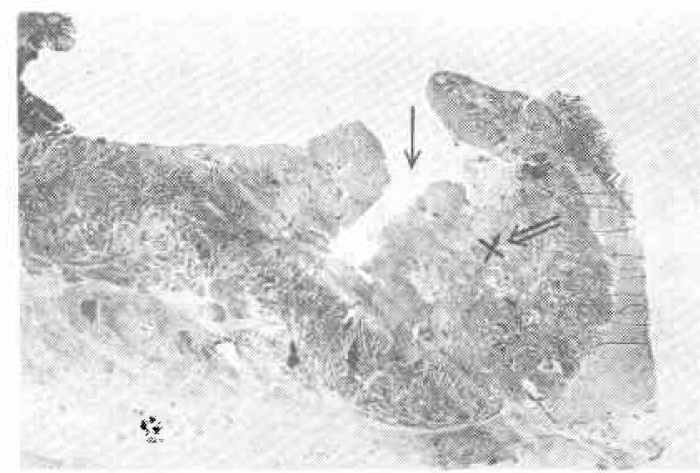

因 8 癌腫内秝室の先端は (†矢卵)くずれている.

anterior resection を行つたが，癌の病期はIV期で あり，根治手術が行えなかつた。

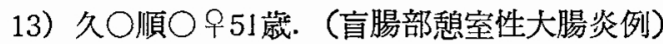
右下腹部痛和よび下痢を主訴として来院し，注 腸透視検查の結果，盲腸，上行および下行結腸に

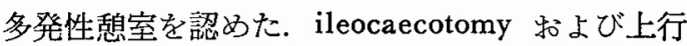
結腸部分切除を施行し治瘉した.

14）加 $\bigcirc$ 高 $\bigcirc 47$ 歳.（悡室穿孔性膿痬例）（図 $9,10,11)$

上腹部痛を主訴として，某内科飞通院加療して いたが軽快せず，上腹部に圧痛を認め，便秘，白 血球増多および発熱があつた。胃透視が行われた 後の腹部単純写真で左横行結腸にバリウムの停滞 をみ，散在性䕀室と狭窄部が認められた。 2 日後 イレウスとなり，注腸透視を行つたところ， $\mathrm{s}$ 状 結腸および横行結腸に狭窄を認めた。開腹すると 左下腹部に小览頭大の限局性膿瘍を認め，これは 想室穿孔性のものであつた. drainage を施行し治 癒した。 


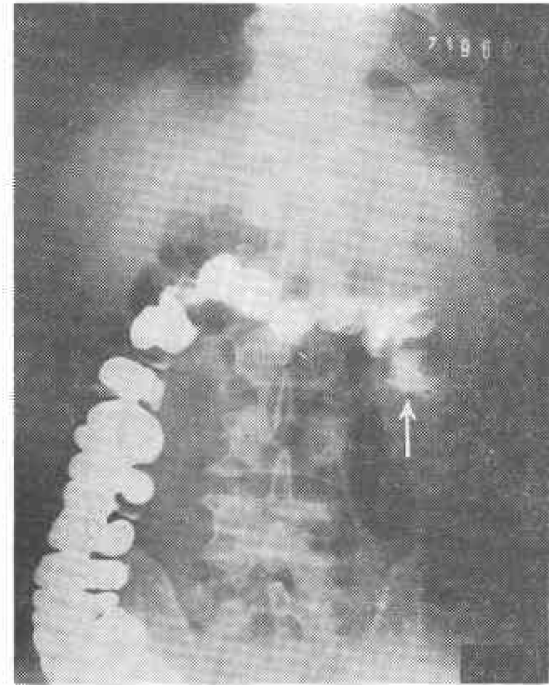

図 9 症例14術前胃透視後の腹部単純 X-P 横行結腸に秝室がみらる。

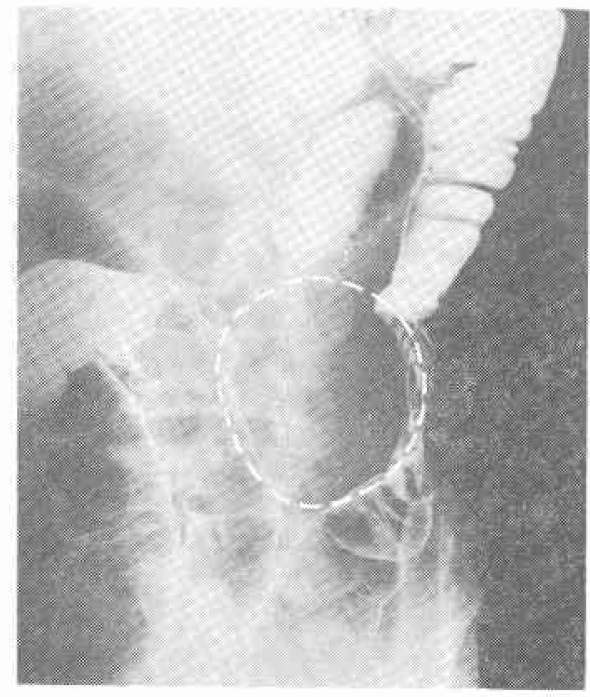

図10 術前注腸透視により横行結腸，下行結腸に狭 窄部および辺緑不整を認めるが，すでに恁窒 は穿孔消失している.開腹時点線内に膿汪を 認めた。

15）丸○幸 $\bigcirc$ ㅇ 21 歳.（盲腸㮩室穿孔性膿瘍例） 石下腹部痛にて，急性虫垂炎として虫垂切除術 を行つたが，術後も白血球増多，右下腹部痛が軽 快せず，注腸透視により盲腸憩室穿孔性膿場と診 断して，再手術により，後腹膜内憩室穿孔性膿瘍 を確認したので, drainage を行つて治癒した.

16）斉 $\bigcirc 2 \bigcirc$ 우 69 歳. (癌併存例) (図一 13 , $14,15,16,17)$

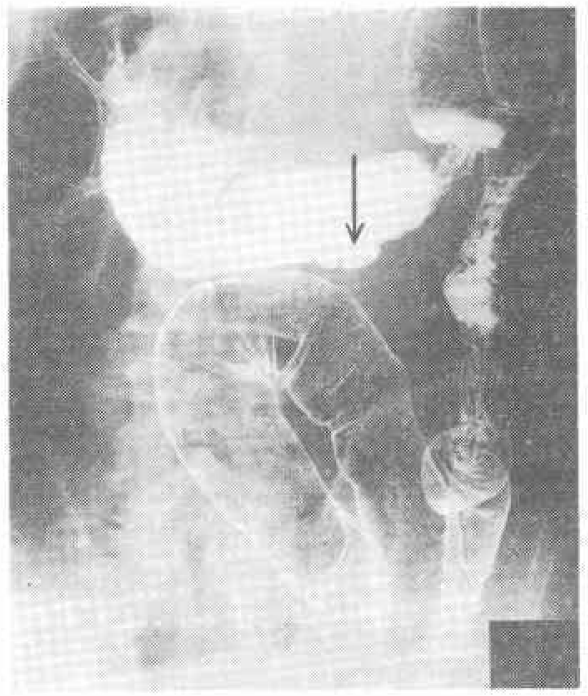

図11 術後（ドレナージ手術）穿孔秘室の残遺が認 められる。

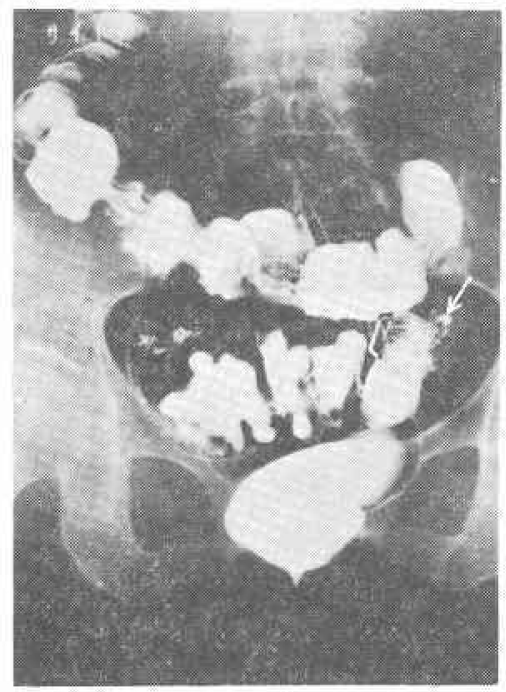

図12症例16个印は癌腫による陰影欠損，粘膜の破 壤がみられる。

下血抢よび排便困難にて入院した。注腸透視お よび大腸フアイバースュープ検查にて，多発性 S 状結腸憩室と S 状結腸癌が認められた。 S 状結腸 切除を施行して，術後 follow up を続けている.

17）佐○良○占74歳.（癌併存例）

排便困難にて某医より転科し，注腸透視劧よび 大腸フアイバースコープ検查にて， $\mathrm{S}$ 状結腸多発 性憩室と S 状結腸癌を認め, 手術を施行したが病 期IVで人工肛門造設のみに終つた。 


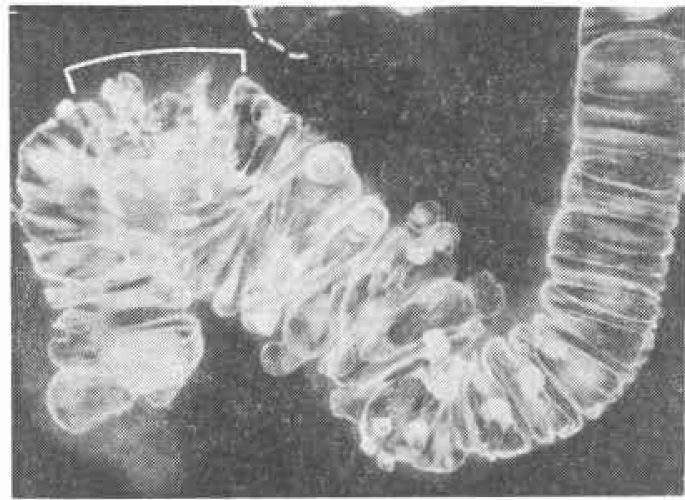

図13 二重造影法では陰影欠損と擤室がょり明 瞭になる。

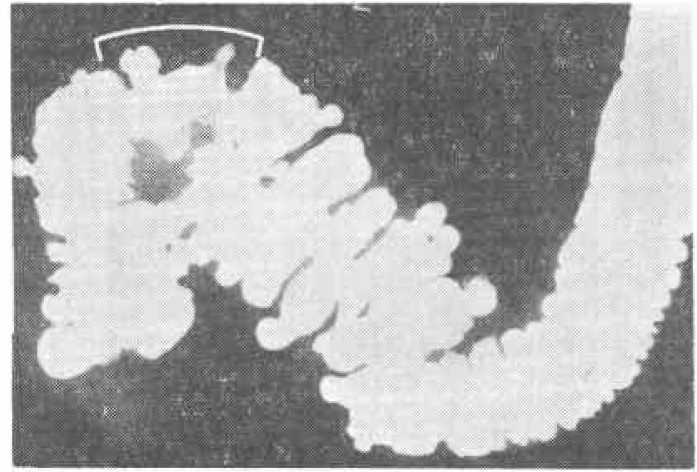

图 14

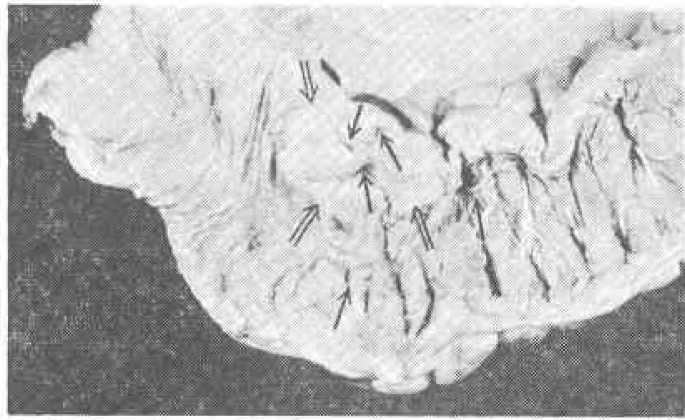

図15（介）印は癌腫でその中に憩室が多数存在. 周囲にも認められる。

\section{6 発生頻度}

Bockus $^{23)}$ Kよれば，1925～1940年の 間に行わ れたレントゲン検査総数 35,256 人中憩室発見は $6.8 \%$ であり，最近の報告頻度は 5 〜 $25 \%$ である と述べている。高齢になれば増加し，Welch ${ }^{24)} は$ 2,000 例の注腸透視で60歳代では20\%，85歳では 66\% が大腸に数室を有すると報告している．本

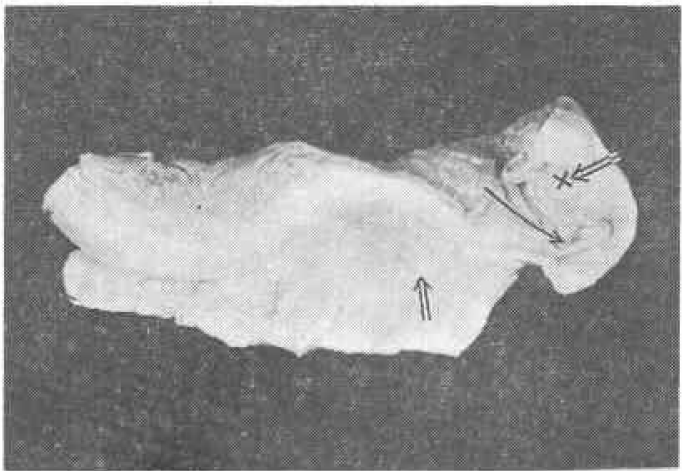

因16横断面をみると憩室が明らかに腫瘍内に みられる。

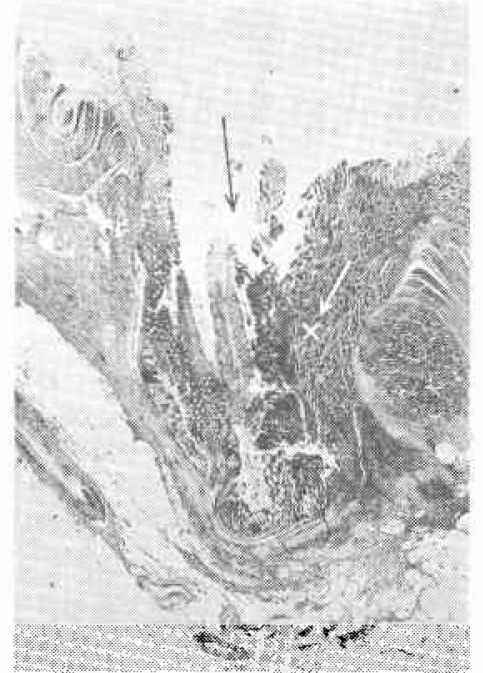

図17（†）印に憩室がみられ，その壁に癌腫の浸 㵎がみられる，筋層にも癌腫がみられる。

邦では表 2 のごとく，1970年以前はその報告発生 頻度は非常に低く，これらのデータが日本人には 大腸蒩室が少いといわせたものである．しかし 1971年以後はその発生頻度も増加し，一般に大腸 䫁室の認識が広まつたことを示す，とくに吉川 ${ }^{182}$ の $9.6 \%$ は 1 年間に扱かつた症例の検討であるた め，最近の本邦に括ける発生頻度をよくあらわし ているものと考えられる. 小坂 ${ }^{17}$ は70歳以上の男 性において検查 54 例中 12 例 $22.2 \%$ すなわち 5 人に 1 人の割合で発見されたと報告して拈り，本邦に 执いても老人に多いことがわかる．著者の頻度は 4.5\%（27/600）で決して多くはない。これは検 查を行つた時期が古く，大腸憩室症の認識が低か 
表 2 頻 度

\begin{tabular}{|c|c|c|c|c|c|}
\hline 報 告 & 者 & 年 代 & 総 数 & $\begin{array}{l}\text { 大腸憩 } \\
\text { 簘 }\end{array}$ & $\%$ \\
\hline 藮 & 殿 & 1954 & 13,000 & 1 & 0.0077 \\
\hline 松 & 永 & 1966 & 3,200 & 4 & 0.12 \\
\hline 久 & 保 & 1969 & 2,592 & 55 & 0.0212 \\
\hline 牧 & 野 & 1961 & 2,627 & 1 & 0.0004 \\
\hline 黒 & 滝 & 1968 & 368 & 11 & 0.0298 \\
\hline 藤 & 島 & 1970 & 457 & 6 & 0.0131 \\
\hline 粕 & 川 & 1971 & 600 & 27 & 4.5 \\
\hline 小 & 圾 & 1971 & 1,987 & 131 & 6.6 \\
\hline \multirow{2}{*}{ 菅 } & \multirow{2}{*}{ 原 } & \multirow{2}{*}{1971} & $\begin{array}{c}\text { 経 口法 } \\
1,172\end{array}$ & 29 & 2.5 \\
\hline & & & $\begin{array}{c}\text { 経肛門法 } \\
728 \\
\end{array}$ & 38 & 5.2 \\
\hline \multirow{2}{*}{ 池 } & \multirow{2}{*}{ 永 } & \multirow{2}{*}{1971} & $\begin{array}{c}\text { 経 口 法 } \\
633\end{array}$ & 26 & 4.1 \\
\hline & & & $\begin{array}{c}\text { 経肚閒法 } \\
715\end{array}$ & 46 & 6.4 \\
\hline 吉 & 川 & 1971 & 700 & 68 & 9.6 \\
\hline 稙 & 松 & 1971 & 413 & 16 & 3.8 \\
\hline
\end{tabular}

つた時のものが多かつたためである.

\section{7 症状}

\section{1）大腸秘室 :}

大腸に㮃室があり，炎症その他の合併症のない ものでは生涯無症状に経過するものが多い，しか し，臨床的には炎症などの所見がないにるかかわ らず，不定の胃腸症状を伴らものがある. とくに 多発性㮩室で部分的であつても spastic colon を 伴うものはそれなりの症状が出現する。これは憩 室そのものの症状ではなく， spastic colon の症 状であり，多くは腹痛，腹部膨満感扣よび便秘ま たは下痢を伴らことがある。この時期の直腸鏡診 では粘膜の軽度発赤, 軽度の浮腫を伴い一見大 腸炎の初期を思わせる所見をるる. 粘膜の試験切 除を行らと軽度に浮腫を伴い, 慢性炎症性細胞 の増多をみ，多くの場合病理学者は非特異的な 軽度の慢性炎症と診断するが，しかしこれらの所 見だけで想室の診断の助けとはならない. Spriggs $ら^{229}$ は 100例中71例に症状があり，29例は無症状 であつたと次のように症状を表示している.

\section{Constipation......53cases}

Flatulence......22cases

Abdominal pain.....21cases

Abdominal dicomfort, disstention or indigestion ......21 cases
Pain or discmfort before or after defecation .....6cases

\section{Diarrhea.....6cases}

Irregular micturition......4cases

Alternating constipation and diarrhea......3 cases

2）熹室性大腸炎 :

炎症を伴なら大腸憩室の症状は種々であり，さ らに炎症による別の合併症を惹起すればなお複雑 な症状を呈する. Asch ${ }^{25)} ら は 475$ 例の diverticulitis の患者を報告し（手術例30\%), abdominal pain, bowel habit abnormality, elevated white blood count and fever がもつとも一般的な症状である と述べている. 手術例についての症状は次のとお りである.
Signs and symptoms

Nausea and vomiting

Abdominal pain alone

Abdominal pain with palpable mass

Constipation

Diarrhea

Genitourinary

Intestinal obstruction

Elevated $\mathrm{WBC}$ and fever

Minor bleeding

Major bleeding

no. of
patient

13

171

36

37

44

25

24

86

23

23

\section{6}

82

17

18

21

12

11

41

11

11

\section{8 検查法およひ診断}

1）症状の分折：大腸䕀室症は多くの場合不定 の胃腸症状のことが多い.また再発性のこともあ り, 大腸㮩室症の疑いがもたれた場合には積極的 に検查を行ら。

2）腹部単純レントゲン検查 : 腸内ガスが多量 に認められる場合（イレウスなど）には腹部単純 レントゲン写真のみで憩室の存在が確認できるこ とがある. 著者は 1 例に認めた。

3）大腸レントゲン透視法 : 注腸透視法が現在 喤室の診断法としては最有力な武器である.これ には Fischer 法, Welin 法扰よびその変法, 経 口法などがあるが，それぞれ一長一短で，そのケ 一スにより方法を選ぶべきである.

Fischer 法の欠点は(1)一旦注入された造影剤の 
排出が不十分となると腸管が重なつているところ は診断できないこと，(2)同様に造影剤排出不十分 な所の腸管の辺縁以外の憩室は発見できないこ と，(3)腸管内王が過上昇し，喤室性大腸炎では穿 孔の危険があることである. Welin 法扝よびその 変法の欠点は(1)バリウムが高濃度少量のために， 十分に全大腸に拡がらないこと，とくに唕室性大 腸炎ではバリウムの乗りがわるく不十分である， (2)空気注入により腸管内圧が過度に上昇する危険 があること，(3)重症患者または体位変換ができな い患者には施行しがたいことである．経口法の欠 点は(1)厳重な前処㯰を要すること，(2)腸管に狭窄 のある患者には施行できないこと，(3)経肛門法よ り多少診断能が低下すること，(大腸にバリウム が達する時間が人により異なり，時にタイミング を失することがある)である。

憩室炎のいかなる病期にも，バリウムによる注 腸透視には禁忌はないと Goulard ${ }^{36)}$ らも述べてい るよらに，著者も積極的に行つている. しかし， 施行上に二三の注意が必要である.Arfwindsson ${ }^{27)}$ らは正常人大腸と憩室症患者の腸管内圧を種々の 条件で測定している. それによると安静時でも悪 室症患者の方が明らかに高く，食後およびプロス チグミン投与後には馝室症患者の方が著明に上昇 する. またモルフイン，感情の動よう，機械的刺 激などで腸管の分節運動を増加させ, 内王波の数 る振幅も増加する.リチネイックアシッドは小腸 の運動を主として京進させ，二次的に大腸の運動 る元進させるといわれている。すなわち㗍室症患 者の取扱いには腸管の運動を六進させるような処 置和よび薬物投与は最小限とすべさである．著者 の症例一11は術前検査のためにりチ亦油 $30 \mathrm{ml}$ 投与した症例であり，今後とくに注意すべきこと がらである.

(1)前处置には硫動パラフインの投与を行う， (2)ブスコパンなどは使用しない，(3)洗腸はとくに ゆつくり行う（注入速度）,(4)できれば前日は低残 渣食とする，(5)バリウムの濃度はとくに低濃度と する ( 2 倍以上に薄める), (6)空気注入により腸管 を過伸展としない，(7)検査終了したら排便させて 後に，または翌日腹部単純レントゲン写真を撮影 する（これで稳室内バリウム残留像が明らかにな
る).以上の注意でより安全にかつ適確に大腸䅫室 症の診断ができる.ただしこれは合併症のある場 合にとくに有用であり，炎症などを伴わない場合 はここまで注意しなくともよい，一方最近胃腸管 のスクリーニング（ドック形式または集団検診） が普及し, 大腸にもこの傾向は強くなつている. この場合には主力は経口大腸透視法であり，これ らのデータの発表が増加している.

\section{4）直腸鏡検查 :}

$\mathrm{S}$ 状結腸下部までの憩室は直接観察することが でき, 外来でる手軽に施行できる検査であり，こ れもまた有用である. 著者の症例では 9 例に直腸 鏡検査を施行し，1例に肛門緑より11 cmの部位に 直腸䕀室を認め, 炎症による狭窄を認めたもの 3 例, 直腸鏡の致達外の口側腸管より血液の流出 を認め，憩室の診断に役立つたものが 2 例ある. Buie ${ }^{28)}$ はS 状結腸の顋室症の存在を強く疑わせ， または時にこれらの存在を決定しらる 5 種類の直 腸鏡所見を記載している.すなわち，

\section{(1)腸管の可動性の減少}

普通は可動性である腸管分節の可動性の減少は 本症の疑いを起させる. 可動性の減少に加えて, その他の 1 ないしそれ以上の異常所見が認められ るならば，その原因が憩室炎にある可能性は相当 に強いものである.

(2)腸管の屈曲

腸管の屈曲はそれだけでは診断の根拠となるも のでないが，多分に暗示的存在である. また可動 性の減少和よび粘膜浮腫の屈曲ととも認められ ればより確定的である.

(3)腸管腔内径の減少

この所見は㮩室炎患者にはしばしば認められ る. 炎症が軽快して, 線維化が起れば, 腸管内径 は縮少する、活動性の敗室炎が存在する時に腸管 腔の狭少化が認められるのが普通である.

(4) sigmoidal sacculation (小霊形成)

sigmoidal sacculation は粘膜筋層の弱い箇所に 起り，しばしば老人にみられる，直腸鏡検査上は 浅い袋のよらにみえるが，時には深く大きく， 直腸鏡の先端をその中に入れられる汪どのものも あり，このため重複腸管かと感じられるものもあ る. またとの深部にある喤室を值接認めることも 
ある.総じてこのような sacculation は炎症を起 していない可動性の $\mathrm{S}$ 状結腸に認められる. 著者 は sigmoidal sacculation は強く䄭室症の存在を 暗示するものと考えて和り，この所見があつて数 室の不明なものは注腸を行ら。しかしこれで㮩室 の存在を確かめえなかつた症例を数例経験してい るが, これらの症例では $1 \sim 3$ 年後のX線検查に より悡室の存在が証明されている.

(5)㮩室の観察

憩室の存在を観察しうるものは総じて炎症が存 在しない時だけに限られる。時沈内腔に突出した ポリープ様にみられることもある. Jackman ${ }^{29)} ら$ は 160 例の直腸鏡可視範囲内にある憩室症の観察 結果を次のように報告している.

35例 $(22 \%) \cdots \cdots .$. 直接憩室を観察.

72例 (45\%) …...sacculation を認める.

53例 (33\%) …… 状結腸の可動性消失.

強い屈曲, 粘膜浮腫叔よび直 腸外腫瘍の所見あり。

5）大腸フアイバースコープ

最近大腸フアイパースュープの普及が目ざまし く，この検査により大腸憩室は明瞭に診断がで き，また内腔を直接観察することにより，合併症 の有無およびその状態がつかめ，写真による再現 性があり, 試験切除も同時にできるため, 癌の併 存にはとくに有用で，著者も積極的に利用してい る. 症例一 $10,12,16,17$ はこの検査により，癌 と憩室が同時に診断しえた症例である.

\section{合併症}

大腸秝室は炎症を基盤として，種々の合併症を 惹起する. 成書によれば，1）出血，2）喤室性 大腸炎，3）憩室性膿瘍，4）憩室性大腸狭窄,

5）喤窒穿孔性瘦孔，6）悡室穿孔性腹膜炎（沉 発性または限局性）などとされている，著者の症 例も以上の合併症をいずれも若起したものであ る. 時に癌の合併も考光られるので注意を要する （項を改めて述べる）。

とくに糖尿病の患者は合併症を起しやすいよう に考えられるが, Schowengerdt ${ }^{30)}$ らは 740例の想 室性大腸炎および多発性䕀室症の患者を調査した ところ，各々 $22.8 \%(47 / 206), 10.5 \%(26 / 534)$ に糖尿病を有していたが，その合併症を膿瘍，穿
孔, 出血, 瘦孔形成なぞそついて比較検討して, 意外にも㝆室性大腸炎に和ける出血のみに有意の 差があるのみであつた(23.4\%: 14.5\%) と報告し ている．合併症のある患者ではただちに治療方針 をたてることが必要であることは言を待たない。

\section{0 癌腫と㮩室の併存について}

著者らの大腸熄室症患者32例の中で, 手術を行 $つ た 17$ 例中 6 例（約 $35 \%$ ）飞唕室と癌が併存して いた，全憩室症患者に対する頻度は約 $19 \%$ （6/ 32）であつた，欧米の報告例をみると，Wilson ${ }^{311}$ $26.7 \%$ (4/15), Bacon $\left.{ }^{32}\right)$ 10.7\% (20/186), Pemberton $^{88)} 25 \%$, Laufman $^{34)} 1.5 \sim 8 \%$, Ming $^{35)}$ 24\%（21/83）などであり，著者らの頻度は欧米 にくらべて決して少いるのではない，本邦におい て癌腫之憩室が同一部位に存在する症例の発表は きわめて少ない，著者があつめえた範囲では 4 例 で, 著者らの症例も加えて 9 例のみでめつた。

本邦の報告症例 :

報告者

1) 杉本直伸：76歳令， $\mathrm{S}$ 状結腸䄭室 $+\mathrm{S}$ 状結 腸癌, 大腸肛門誌 $20: 87,1966$.

2）松永内科：66歳令， $\mathrm{S}$ 状結腸憩室 $+\mathrm{S}$ 状結 腸癌，宮城らの全国集計による（未発表例）。

3）宮城伸二：65歳今， S 状結腸㮩室 $+\mathrm{S}$ 状結 腸癌, 胃と腸 3 : $331,1968$.

4）久保田護：61歳令，盲腸䕀室十盲腸癌，日 消会誌，65：114，1968.

5）粕川剛義：72歳令, 下行結腸䓌室十下行結 腸癌,

70 嵅 $\hat{O}$, 全結腸憩室十直腸 S 状結腸部癌. 65歳令,下行就よび $\mathrm{S}$ 状結腸㓤室+ $\mathrm{S}$ 状結腸癌. 以上, 大腸肛門誌25: 4, 1972.

6）今回 2 例を追加した.

以上の症例をみると男性 8 : 女性 1，61～69歳 : 5 例, 70 歳以上 : 4 例, 癌発生部位, $\mathrm{S}$ 状結腸 ： 7 例, 盲腸： 1 例, 下行結腸： 1 例で $\mathrm{S}$ 状結腸 が大部分を占め，60歳以上ではみられなかつた。

唕室性大腸炎や多発性憩室症が癌を覆つたり，

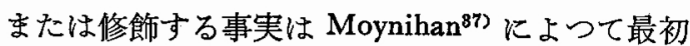
飞強調され，そのような 6 症例を報告した。以後 Mayo \& Blunt ${ }^{88)}$, Edwards, Jones ${ }^{89)}$ らがこれを 認めている. Jones は 3 カ月で癌に変化したとい 
う最初の 1 例を報告し，また覟室性大腸炎で切除 した標本で，病理学者によつて癌と訂正された ものは18\%であつたと報告している. Ponka ${ }^{399}$ は 355例の結腸癌のちち75例（31\%）に憩室性大腸 炎扣よび多発珄憩室症が認められ，そのらち35例 のS 状結腸癌が S 状結腸秝室に密接に関係してい たと報告し，㮩室性大腸炎和よび多発性憩室症が ある患者で強い症状のある場合は癌の併存を無視 すべきでないと述べている．Wilson ${ }^{31)}$ は下部大 腸㮩室症で手術した15例中 4 例は憩室から癌が発 生したるのとし，これは鄎室の慢性炎症によつて 遊離した上皮より発生したものとした．本邦では 斉藤 ${ }^{403}$ が71歳への下行拈よび $\mathrm{S}$ 状結腸憩室症の手 術例を報告し，㮩室壁の組織所見をみると，癌性 変化も充分ありうると述べている. その他多くの 報告があるが，賏室より癌が発生したという決定 的なものはない，著者の症例でもそれが十分に考 えられる症例もあるが（症例一1，小平による）， 決定はでさない，手術所見や摘出標本で明らかに 憩室と癌が併存して括り，手術された時点では憩 室を癌がまきこんでいる.これらの症例はレント ゲン写真だけでも充分に，癌の疑いのもたれるも のもあるが，多くの場合多発性憩室の炎症による 二次的変化をきたした腸管では診断が困難である と考えられた。 しかし，摘出標本による注腸造影 法では明らかに二重造影法がすぐれて和り，透視 の条件さ党そろ亲ば，十分に診断可能と考兄られ た.

\section{1 治療}

大腸秝室症の治療は内科的および外科的にわけ られる. まず手術の適応についてみると， Botsford ${ }^{41)}, W e l \mathrm{ch}^{24)}, \mathrm{Asch}^{25)}$ らは次のように報告し ている.

\begin{tabular}{|c|c|c|c|}
\hline & Welch & Botsford & Asch \\
\hline Diverticulitis & $38 \%$ & & \\
\hline Perforation & $27 \%$ & $12 \%$ & $23.1 \%$ \\
\hline Fistula & $10 \%$ & $9 \%$ & $10.9 \%$ \\
\hline Obstruction & $2 \%$ & $2 \%$ & $5.0 \%$ \\
\hline Bleeding & $5 \%$ & $4 \%$ & $11.0 \%$ \\
\hline Pelvic abscess & & $10 \%$ & \\
\hline $\begin{array}{l}\text { Persistent disease } \\
\text { manifested by local } \\
\text { pain \& palpable mas }\end{array}$ & & $44 \%$ & 5.7 \\
\hline
\end{tabular}

Rule out carcinoma $\quad 8.6 \%$ ? Appendicitis $\quad 4.2 \%$ Miscelaneous $\quad 4.7 \%$ $\begin{array}{llll}\text { Total cases } & 114 & 100 & 209\end{array}$

これにより手術適応の全容がわかる.これ以外の 意室性大腸炎は内科的に行ら. その要点は抗生物 質の投与, 腸管の安静(腸運動の六進する薬物の 投与拉よび処置の禁止), 流動パラフインの投与 (これはかなり効果があり，また便秘傾向のある 患者には著効を奏する）である。

外科的治療の主流は羅患腸管の一次的切除であ り，膿瘍形成に対しては排膿ドレナージである。 瘦孔は合併切除を行う。

\section{2 総括およひ結語}

近年大腸棃室症の報告は増加し，日本において もその発生頻度は欧米なみに近づき, 約 $9.6 \%$ ま で上昇している. 本症の発生頻度の増加は当然治 療対象となる合併症々例の増加が考兄られる.こ の疾患の原因または病因は種々の研究 および報 告734243(4) 45)48)47783493がなされているにもかかわ らず，いまだ確定的なるのはない. 㓤室発生には 腸管自身の異常に加之, 内圧の異常または運動の 異常が考古られる. 著者は東邦大学第 1 外科教室 に郝ける32例の手術例をまとめて発表したが，そ の内 6 例に同一部位に䄭室と癌が存在している症 例があり，文献考察を加えて種々検討した．本邦 に持けるこのような症例は少く，9例であつた が，当教室例は 6 例に及び，なにゆ穴このように 多いのであるか考えさせられた．9例の癌併存例 を検討するとその特徴は(1)男珄に圧倒的に多いこ と（8：1),(2)すべて60歳以上で80歳以上に認み ないこと, (3) S 状結腸部を中心にした多発性嚊室 症が多い(6/9), (4)症状としては下血型怙よび 狭窄型であること，(5)注腸透視像では毠室周囲炎 または膿瘍形成などにより強く腸管自身の変形を 伴わない場合は，陰影欠損として診断が容易につ くこと，(6)狭窄型は直腸鏡和よび大腸フアイバー スコープによる腫瘤の試験切除を行っても，一 回で癌組織が認められないことが多い（4例中 2 例，50\%).これは憩室炎のために，癌周团組織ま たは腸管に炎症が波及し，癌が桨症性反応で修飾 されるためと考えられた。このような症例ではあ 
くまでる癌の併存を考光, 試験切除をくり返し行 うべきであることを強調する.

（本文の要旨は第26回日本大腸肛門病学会のシンポ ジウムで発表した。

稿を終るにあたり，東邦大学第1 病理学教室秋間道夫 講師, 一森助手, 東邦大学第 1 外科教室吉雄敏文助教授 の御援助和よび 東邦大学第 1 外科教室亀谷寿彦教授の 御校閲に深謝する。

全国集計の資料を提供してくださった順天堂大学第 1 外科教室宮城伸二講師に就礼を述べる).

\section{文献}

1) 宮城伸二 : 自験結腸秝室45例の観察より引用, 大腸肛門誌, 25 (1):3-4, 1972.

2) Cruveilhier, J.: Traite dAnatomie pathologique, Paris, Bailliere, 1: 593, 1849.

3) Ball, C.B.: The Rectum and Anus: Their Diseases and Treatment, 396-400, Cassell, Co., London. 1887.

4) Graser, E.: Entzundlich Stenose des Dickdarmes bedingt durch Perforation multipler falscher Divertikel, Centralbl. chir. 25: 140142, 1898.

5) Beer, E.: Some pathological and clinical aspects of acqired (false) diverticula of the intestines, Am. J. M. Sc., 138: 135, 1907.

6) Mayo, W.J.: Aquired diverticulitis of the large intestine, Surg. Gynec. Obstet. 5: 8-15, 1907.

7) Morson, B.C.: The muscle abnormality in diverticular disease of the sigmoid colon. Brit. J. Radiol. 36: 385-406, 1963.

8) Painter, N.S.: Diverticular disease of the colon, Brit. Med. J. 24: 475-479. 1968.

9) Hughes, L.E.: Postmortem survey of diverticular disease of the colon, Gut 10: 336-351, 1969.

10）園田左武郎：腸蒩室二因スル腸捻転症及ビ棃 室炎, 各 1 例二就テ, 軍医団雑誌, $249: 387-$ 396, 1934 .

11）松尾信吉：虫様垂突起炎と誤診した横行結腸 頽室炎，大阪医事新誌， 7:1006, 1936.

12）日下部旦三: 興味ある゙ラーゼル氏稳室炎穿 孔 2 治験例, 日臨外誌, $2: 730-732,1939$.

13）武田義章洁か: 盲腸箇室炎の二症例, 東西医 学, 6:50-57, 1939.

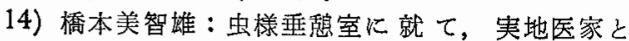
臨床, $17: 1-3,1940$.

15）野口好之：腸管愁公について（十二指腸䄸室 並びにメッケル氏䕀室を除く), 実践医理学, $10: 474-490,1940$.

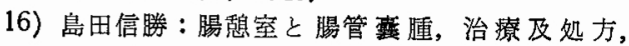
$22: 1074-1083,1941$.

17）小坂知一郎泟か：結腸㮩空症について，大腸
肛門誌, 25 (1):5-6, 1972 .

18）吉川保雄浮か：大腸稳室（症）に関する臨床 的X線学的研究, 大腸肛門誌, 25(1):11一 $12,1972$.

19）小出来一博活加：結腸鄎室炎，医事新報, 2207 : 7-10, 1966.

20) Quervain, F. de.: Zur Diagnose der erworbenen Dickdarmdivertikel und der Sigmoiditis diverticularis, Dtsch. $Z$. Chir. 128: 67-85, 1914.

21) Case, T.T.: The roentgen demonstration of multiple diverticula of the colon, Am. J. Roentgen. 2: $654-658,1915$.

22) Spriggs, E.I. and Marxer, O.A.: Intestinal diverticula, Quart. J. Med., 19: 1-34, 1925.

23) Bockus, H.L.: Gastroenterology, Sec. Ed. 919-953, W.B. Saunders, Philadelphia, London. 1969.

24) Welch, C.E. et al.: Appraisal of resection of colon for diverticulitis of sigmoid, Am. J. Surg. 138: 332-343, 1953.

25) Asch, M.J. et al.: Diverticulitis coli; A surgical appraisal, Surgery, 62: 239-247, 1967

26) Goulard, A.Jr. et al.: Correlation of the clinical, pathological and roentgenological findings in diverticulitis, Am. J. roentgen. 72: 213-221, 1954.

27) Arfwindsson, S. et al.: Intraluminal pressure in the sigmoid colon of normal subjects and patients with diverticular disease of the colon. Acta Chir. Scand., 342: 11-26, 1964.

28) Buie, L.A.: Diverticula of the colon, New Engl. J. Med., 221: 593, 1939.

29) Jackman, R.J. et al.: Divertcula of the colon. Proctoscopy as an aid in the diagnosis and differential diagnosis, J.A.M.A. 121: 1144, 1943.

30) Schowengerdt, C.G. et al.: Diverticulosis, diverticulitis, and diabetes, A review of 740 cases. Arch. Surg. 98: 500-504, 1969.

31) Wilson, L.B.: Diverticula of the lower bowel: Their development and relationship to carcinoma, Ann. Surg. 53: 223-231, 1911.

32) Bacon, H.E.: Anus, Rectum, Sigmoid colon, Diagnosis and Treatment, 3rd Ed., J.B. Lippincott, Co. Philadelphia, 1949.

33) Pemberton, J.J. et al.: Progress in the surgical management of diverticulitis of the sigmoid colon, Surg. Gynec. Obstet. 85: 523-534, 1947.

34) Laufman, H.: The Surgical management of diverticulitis of the colon, A 5-year collective review. Internat. Abstr. Surg. 73: 222-223, 1941.

35) Ming, S. et al.: Diverticulitis of the sigmoid 
colon: Reappraisal of the pathology and pathogenesis, Surgery, 58: 627-633, 1965.

36) Mayo, C.W. et al.: The surgical management of the complications of diverticulitis of the large intestine, analysis of 202 cases, Surg. Clin. North Amer. 30: 1005-1012, 1950.

37) Moynihan, B.G.A.: Mimicry of malignant disease of the large intestine, Brit. Med. J. 2: $1817,1906$.

38) Jones, D.F.: Diverticulitis of colon: its relation to carcinoma, New Engl. J. Med., 203: 459, 1930.

39) Ponka, J.L. et al.: Coexisting carcinoma and diverticula of the colon, A.M.A. Arch. Surg. 79: 373-384, 1959.

40) 斉藤 晃 : 結腸悡室症の一手術例, 日本处科宝 函, $32: 595,1963$.

41) Botsford, T.W. et al.: Diverticulitis coli, criteria of management for the physician and the surgeon, New Engl. J. Med., 265: 618623, 1961.

42) Painter, N.S.: The effect of morphine in diverticulosis of the colon, Prog. Surg. 141: 674-685, 1955.

43) Parks, T.G. et al.: Motility stuuies after resection of the sigmoid colon for diverticular disease, Brit. J. Surg. 55: 867, 1968.

44) Torsoli, A. et al.: The relationships between anatomy and motor activity of the colon, Amer. J. Dig. Dis. 13: 462-467, 1968.

45) Noer, R.J.: Hemorrhage as complication of diverticula, Ann. Surg. 141: 674—685, 1955.

46) Williams, I.: Diverticular disease of the colon without diverticula, Radiology, 89: 401-412, 1966.

47) Colcock, B.P.: Diverticular Disease of the Colon, MPCS. 11: 8-9, W.B. Saunders Co. Philadelphia, London, Toronto, 1971.

48) Fleischner, F.G.: Diverticular disease of the colon, New observation and revised concepts, Gastroenterology, 60: 316-324, 1971.

49) Slack, W.W.: Diverticula of the colon and their relation to the muscle layers and blood vessels, Gastroenterology, 39: 708-712, 1960. 